\title{
Potential of Malacca leaf (Phyllanthus emblica) against Salmonella sp
}

\author{
Nuzul Asmilia ${ }^{1,2^{*}}$, Mahdi Abrar $^{3}$, Yudha Fahrimal $^{4}$, Amalia Sutriana ${ }^{5}$, and Yobeswi Husna ${ }^{6}$ \\ ${ }^{1}$ Study Program Doctor Mathematical Applied Science Universitas Syiah Kuala, Banda Aceh 23111, Indonesia \\ ${ }^{2}$ Clinical Laboratory Veterinary Medicine Universitas Syiah Kuala, Banda Aceh 23111, Indonesia \\ ${ }^{3}$ Microbiology Laboratory Universitas Syiah Kuala, Banda Aceh 23111, Indonesia \\ ${ }^{4}$ Parasitology Laboratory Universitas Syiah Kuala, Banda Aceh 23111, Indonesia \\ ${ }^{5}$ Pharmacology Laboratory Universitas Syiah Kuala, Banda Aceh 23111, Indonesia \\ ${ }^{6}$ Veterinary Study Program, Faculty of Veterinary Medicine, Universitas Syiah Kuala, Banda Aceh 23111, Indonesia
}

\begin{abstract}
Malacca is one of traditional medicine that possesses a potent antimicrobial activity. This study aims to determine the inhibitory activity of Malacca leaf extract on the growth of Salmonella sp in vitro. The bacteria was obtained from Microbiology Laboratory of the Faculty of Veterinary Medicine, Universitas Syiah Kuala. The study was conducted using n-hexane extract, ethyl acetate extract and ethanol of malacca leaves with dilution concentrations of 5\%,25\%, and 50\%.The inhibitory property of malacca leaf was tested using Kirby-Bauer method. Data were analyzed descriptively. The results of this study indicate that $n$-hexane extract, ethyl acetate extract and ethanol extract of malacca leaves can inhibit the growth of Salmonella sp. The n-hexane extract of malacca leaves showed a greater inhibition than the ethyl acetate and ethanol extract of malacca leaves. n-hexane extract with a concentration of 5\%,25\%, and 50\% showed average diameter inhibition of $1.35 \mathrm{~mm}$ (weak), $4.97 \mathrm{~mm}$ (moderate), and $12.87 \mathrm{~mm}$ (strong), respectively ethyl acetate extract with a concentration of 5\%, 25\%, and 50\% showed average diameter inhibition of $2.00 \mathrm{~mm}$ (weak), 5.72 $\mathrm{mm}$ (moderate), and $7.58 \mathrm{~mm}$ (moderate), whereas in ethanol extract were $0.47 \mathrm{~mm}$ (weak), $2.58 \mathrm{~mm}$ (weak), and $4.35 \mathrm{~mm}$ (weak), repectively. The clear zone areas in negative and positive control were $0.00 \mathrm{~mm} 20.00$ $\mathrm{mm}$, respectively. Malacca leaf extract possess inhibitory property against the growth of the Salmonella sp.
\end{abstract}

Keywords: Malacca leaves, Salmonella sp, Kirby-Bauer Method.

\section{Introduction}

Antibiotics are usually used as antimicrobial drugs when an infection occurs, thus shortening the suffering and reducing the possibility of complications. Inappropriate use of antibiotics must be avoided because it can cause antibiotic resistance [1]. Plants in general can produce compounds that can inhibit the growth of microbes [2]. One of the plants that has been widely used as a medicinal plant is the leaf of Malacca (Phyllanthus emblica).

Kaur et al. [3], stated that Malacca is a plant that is believed by the community as traditional medicine that can cure various diseases, treat diabetes, as an analgesic, hepatoprotective, antipyretic, anti-inflammatory, anticancer, antihyperlipidemic, and antidiarrheal. The results of phytochemical examination of malacca leaves showed the presence of alkaloids, flavonoids, tannins, saponins, and terpenoids which were thought to be active as antimicrobials [4]. Some studies suggest that malacca leaves have activity in inhibiting the growth of microbes, as explained by [5], stating that malacca has antimicrobial activity against Staphylococcus aureus and Klebsiella pneumonia. Research by [4], using ethyl acetate extract of malacca leaves to inhibit the growth of Gram negative bacteria such as Escherichia coli.

Salmonella $\mathrm{sp}$ is a gastrointestinal pathogenic bacteria that causes foodborne disease. This bacterium has parasitic properties that cause inflammatory intestinal tract reactions [6]. The spread of these bacteria can be through feces which then contaminate food or water sources. The most frequent source of Salmonella sp infection is contaminated water, feces, milk or processed products that are contaminated or through an imperfect pasteurization stage, to meat and eggs of livestock [7].

The occurrence of salmonellosis is caused due to contact with cattle dung, contaminated water or waterborne disease, and the environment [8]. Some of the main diseases that are infected by Salmonella sp were enterocolitis and typhoid fever. Based on the above information, the authors were interested in conducting research on the antimicrobial activity of n-hexane, ethyl acetate and ethanol extracts of malacca leaves against Salmonella sp.

The purpose of this study was to determine the inhibitory activity of malacca leaf extract on the growth of Salmonella $\mathrm{sp}$ in vitro and determine the most effective

* Corresponding author: nuzulasmilia@unsyiah.co.id 
concentration of malacca leaf extract in inhibiting the growth of Salmonella sp

\section{Materials and Methods}

\subsection{Research Samples}

Malacca leaves used are perfectly grown leaves taken from malacca trees in Aceh Besar region. Isolate Salmonella sp from the isolate of the Microbiology Laboratory, Faculty of Veterinary Medicine, Syiah Kuala University.

\subsection{Preparation of Malacca Leaf Extract}

Malacca leaf extraction is carried out by maceration method. Leaf samples were cleaned and dried, ground to powder, and sieved with 40 mesh sizes. Malacca leaf powder was macerated using 3 different solvents; nhexane, ethyl acetate, and ethanol. Maceration results are filtered using filter paper and the filtrate obtained was collected and evaporated using a vacuum rotary evaporator equipped with a water heater and a vacuum pump until all the solvents evaporate. The extracts obtained were in the form of a paste.

Extracts of n-hexane, ethyl acetate and ethanol of malacca leaves were made with a concentration of $5 \%$, $25 \%$ and $50 \%$. These concentrations were each made using $0.05 \mathrm{mg}, 0.25 \mathrm{mg}$, and $0.50 \mathrm{mg}$ extract of malacca leaves. Concentrations of 5\%, 25\%, and 50\% extract of ethyl acetate were respectively dissolved with tween 80 while n-hexane extract and ethanol extract with distilled water were $0.95 \mathrm{ml}, 0.75 \mathrm{ml}$, and $0.50 \mathrm{ml}$ to $1 \mathrm{ml}$ in volume

\subsection{Phytochemical Test}

$\mathrm{N}$-hexane extract, ethyl acetate extract and ethanol extract of malacca leaves were taken as much as $3 \mathrm{ml}$, then the presence of bioactive compounds was tested by utilizing standard techniques as shown in Table 1.

Table 1. Phytochemical analysis procedures

\begin{tabular}{|c|c|c|}
\hline $\begin{array}{l}\text { Phytochemic } \\
\text { al Content }\end{array}$ & Test Procedre & Observation \\
\hline Steroids & $\begin{array}{l}\text { Liberman- } \\
\text { Burchard/H2SO4 }\end{array}$ & Red or purple color \\
\hline Terpenoids & $\begin{array}{l}\text { Liberman- } \\
\text { Burchard/H2SO4 }\end{array}$ & Red or purple color \\
\hline Saponin & Shaking foam & $\begin{array}{l}\text { Foam } 1-10 \mathrm{~cm} \text { on } \\
\text { adding HCL }\end{array}$ \\
\hline Flavonoids & $\begin{array}{l}2 \mathrm{ml} \text { extract }+ \text { few drops of } \\
\mathrm{NaOH}\end{array}$ & $\begin{array}{l}\text { Yellow color that } \\
\text { clear on adding dil. } \\
\text { HCL }\end{array}$ \\
\hline $\begin{array}{l}\text { Phenolic } \\
\text { Alkaloids }\end{array}$ & $\begin{array}{l}\text { Extract + } 4 \text { drops of } \mathrm{FeCl} 3 \\
\text { Filtrate + Mayer's reagent } \\
\text { Filtrate + Dragendorf } \\
\text { Filtrate + Wagner }\end{array}$ & $\begin{array}{l}\text { Blue-black coloration } \\
\text { White sediment } \\
\text { Reddish sediment } \\
\text { Brown sediment }\end{array}$ \\
\hline
\end{tabular}

\subsection{Inhibitory Test of Malacca Leaf Extract Against Salmonella sp}

Determination of microbial free areas using the diffusion method or Kirby Bauer. Observations and measurements of the diameter of the clear zone that forms around the discs are made after incubating at $37^{\circ} \mathrm{C}$ for 24 hours using a calipers.

Salmonella sp. bacterial culture which has grown on Nutrient Broth (NB) media was compared to Mc.Farland 0.5 . Then bacteria were swab evenly on the surface of the Mueller Hinton Agar (MHA) media and left for 5 minutes. By using tweezers, the blank disks were soaked for 15 minutes in $\mathrm{n}$-hexane, ethyl acetate, and ethanol extracts with concentration of $5 \%, 25 \%, 50 \%$. As negative control, the disks were soaked in tween 80 (control negative for the ethyl acetate extract and distilled water (control negative for ethanol extracts). Paper disks containing the antibiotic chloramphenicol was used as positive control. Each disk paper and chloramphenicol antibiotics were placed on the MHA media, adjusting the distance between the discs in such a way that they were not too close together. The media were then incubated in an incubator at $37^{\circ} \mathrm{C}$ for 24 hours.

The parameter measured in this study was inhibition zone diameter. The data obtained were analyzed descriptively.

\section{Results and Discussion}

\subsection{Malacca Leaf Extraction}

The result of n-hexane extract, ethyl acetate of malacca leaves obtained was blackish-green, has a distinctive odor, and in paste form. The ethanol extract of malacca leaves obtained was dark brown, has a distinctive odor, and alsoin paste form. According to Houghton and Rahman [9], the thing to consider in the selection of solvents is the nature of the material polarity. [10] stated that the extraction time determines the number of components that can be extracted from the material. The extraction time is related to the contact time between the material and the solvent.

\subsection{Phytochemical Content in Malacca Leaf Extract}

Phytochemical test results can be seen in Table.2. Nhexane and ethyl acetate extract of malacca leaves positive contained steroids while terpenoids, saponins, flavonoids, phenolics, and alkaloids were absent. Meanwhile, the presence of saponins, flavonoids, phenolics, and alkaloids were oserved in ethanol extract but the steroids and terpenoids showed negative results.

Some phytochemical compounds of malacca leaves such as alkaloids, flavonoids, tannins, saponins, and terpenoids are thought to be active as antimicrobials [5]. The mechanism of action of steroids as antibacterial is related to lipid membrane and sensitivity to steroid components that cause leakage in bacterial liposomes [11]. Steroids can interact with cell phospholipid 
membranes that are permeable to lipophilic compounds, causing membrane integrity to decrease and cell membrane morphology to change which causes brittle cells and lysis [12]. Antimicrobial activity of terpenoids is thought to involve membrane breakdown by lipophilic components $[13,14]$. Some results showed that terpenoid compounds can inhibit the growth by interfering with the process of the formation of membrane or cell wall, so that the membrane or cell wall is not formed or not formed [15].

Table 2. Phytochemical Content of Malacca Leaf Extract

\begin{tabular}{lrrrr}
\hline \hline Phytochemical & \multicolumn{2}{c}{$\begin{array}{l}\text { Malacca } \\
\text { hexane } \\
\text { Content }\end{array}$} & $\begin{array}{c}\text { n-Malacca } \\
\text { ethyl }\end{array}$ & \multicolumn{2}{c}{$\begin{array}{l}\text { leafEthanol extract } \\
\text { acetateof }\end{array}$} & Malacca \\
extract & extract & leaves \\
\hline Steroids & + & + & - \\
Terpenoids & - & - & - \\
Saponin & - & - & + \\
Flavonoids & - & - & + \\
Phenolic & - & - & + \\
Alkaloids & - & - & + \\
\hline
\end{tabular}

Note: (+) positive contains phytochemical compounds,

(-) negative contains phytochemical compounds

Saponin works as an antimicrobial by disrupting the stability of bacterial cell membranes, causing bacterial cell lysis. So the mechanism of action of saponins is included in the antimicrobial which interferes with bacterial cell membrane permeability, which results in damage to cell membranes and causes the release of various important components from within the cell namely proteins, nucleic acids and nucleotides [16]. Tannins and flavonoids are phenol-derived compounds that are water soluble. Flavonoids work by damaging the cytoplasmic membrane so that the bacteria will be damaged and die [17]. Alkaloids can interfere with the formation of the constituent components of peptidoglycan in bacterial cells which results in the cell wall layer not being formed intact and causing the cell death [18].

\subsection{Inhibitory Activity of Malacca Leaf Extract Against Salmonella sp}

Determination of bacterial sensitivity to antimicrobials was conducted by the diffusion method. The diffusion method could be done in three ways namely: the cylinder method, the corporation method, and the disk diffusion method [19]. In this study the disk diffusion method, known as the Kirby Bauer method, was used wherein the test bacteria were inoculated on agar media and disks containing test solutions as antimicrobials were placed on media containing these bacteria [19].

The presence of clear zone produced around the paper disk soaked in malacca leaf extract was shown in figure 1. Based on the inhibition test of malacca leaf extract against Salmonella sp bacteria using agar diffusion method, it showed the inhibitory properties of the extract against the test bacteria. The inhibitory activity produced was indicated by the formation of a clear zone around the paper disk or extract disk paper. According to [20], the clear zone around disc paper showed the presence of antibacterial activity. In n-hexane extract, the inhibitory power produced was greater than the inhibitory power produced by ethyl acetate extract and ethanol extract. This showed that the active compound that acts as an antimicrobial probably was a non- polar compound. The ability of non-polar compounds to inhibit bacterial growth was related to components of bacterial cell walls that are neither absolute hydrophobic nor absolute hydrophilic.
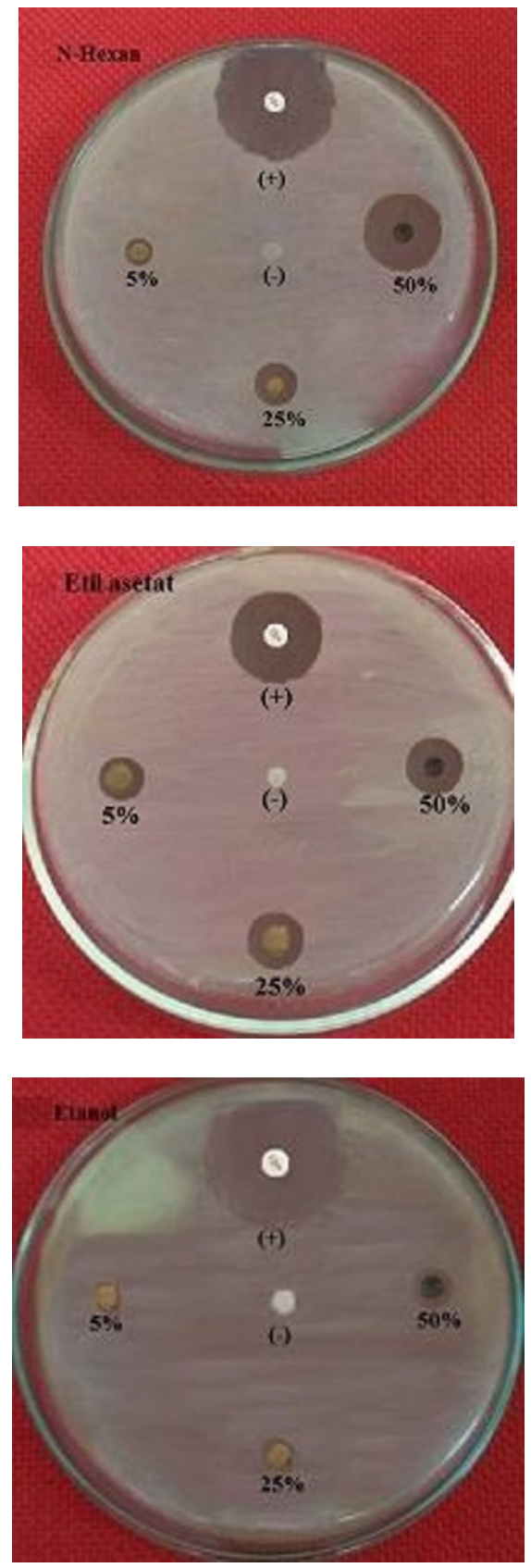

Figure 1. Inhibitory power of malacca leaf extract (n-hexan extract, ethyl acetate extract, ethanol extract) against Salmonella sp.

The average diameter of inhibition of malacca leaves extract against Salmonella $\mathrm{sp}$ was presented in Table 3. Table. 3 showed that the extract of malacca leaves with a concentration of $5 \%, 25 \%$, and $50 \%$ after incubation for 24 hours at $37^{\circ} \mathrm{C}$ could inhibit the growth of Salmonella $\mathrm{sp}$ in vitro. This was indicated by the formation of inhibition zones on the MHA media. The criteria for inhibition strength of antibacterial have a 
category that is $5 \mathrm{~mm}$ diameter inhibition zone or less in the weak category, $5-10 \mathrm{~mm}$ inhibition zone in the medium category, $10-20 \mathrm{~mm}$ is categorized as strong, while $20 \mathrm{~mm}$ or more is included in the very strong category [21].

Table. 3 The average inhibition diameter of malacca leaf extract against Salmonella $\mathrm{sp}$

\begin{tabular}{lcc}
\hline \hline Solvent & Concentration & Average inhibitory diameter $(\mathrm{mm})$ \\
\hline \hline & $5 \%$ & 1.35 \\
N-Hexan & $25 \%$ & 4.97 \\
& $50 \%$ & 12.87 \\
\hline \hline & $5 \%$ & 2.00 \\
Ethyl acetate & $50 \%$ & 5.72 \\
& $5 \%$ & 7.58 \\
\hline & $25 \%$ & 0.47 \\
Ethanol & $50 \%$ & 2.58 \\
\hline
\end{tabular}

The n-hexane extract of malacca leaves showed a greater inhibition than the ethyl acetate and ethanol extract of malacca leaves. N-hexane extract with a concentration of $5 \%, 25 \%$, and $50 \%$ showed average diameter inhibition of $1.35 \mathrm{~mm}$ (weak), $4.97 \mathrm{~mm}$ (moderate), and $12.87 \mathrm{~mm}$ (strong), respectively ethyl acetate extract with a concentration of $5 \%, 25 \%$, and $50 \%$ showed average diameter inhibition of $2.00 \mathrm{~mm}$ (weak), $5.72 \mathrm{~mm}$ (moderate), and $7.58 \mathrm{~mm}$ (moderate), whereas in ethanol extract were $0.47 \mathrm{~mm}$ (weak), $2.58 \mathrm{~mm}$ (weak), and $4.35 \mathrm{~mm}$ (weak), repectively. The clear zone areas in negative and positive control were $0.00 \mathrm{~mm}$ and 20.00 $\mathrm{mm}$, respectively. Clear zone area of $n$-hexane extract and ethanol extract of malacca leaves have a significant differences.

[22], stated that a compound that has optimum polarity will have maximum antimicrobial activity, because for the interaction of antimicrobial compounds a hydrophilic-hydrophobic balance is needed. Hydrophilic properties are needed to ensure the compound can dissolve in the aqueous phase which is a place to live microbes, but compounds that work on hydrophobic cell membranes also require lipophilic properties, so that antibacterial compounds require hydrophilic-lipophilic balance to achieve optimum activity. Some researchers report that the presence of oil in non-polar extracts and protein in polar extracts was a factor influencing the antimicrobial activity of phenolic compounds [23].

Salmonella sp is a group of Gram-negative bacteria that have a more complex wall structure consisting of three layers, namely the outer layer (lipoprotein), the middle layer (lipopolysaccharide), and the inner layer (peptidoglycan). While the structure of Gram-positive cell walls is simpler and consists mostly of peptidoglycan making it easier for antibacterial compounds to enter the cell and find targets to work than Gram-negative bacteria [24]. The composition of the negative Gram bacterial cell wall consists of a high lipid content. These bacteria poses thin peptidoglycan layer contained on periplasmik space, namely the outer membrane with the plasma membrane.
In the outer membrane of the cell wall can protect these bacteria, so it can prevent antibiotics from entering.

\section{Conclusion}

It can be concluded that the extract of malacca leaves can inhibit the growth of Salmonella sp. The higher the concentration of malacca leaf extract used, the larger the inhibition zone diameter formed $n$-hexane extract of malacca leaves at concentration of 50\% shows the highest antimicrobial activity, with inhibition zone diameter of $12.87 \mathrm{~mm}$ (strong) against Salmonella $\mathrm{sp}$.

\section{References}

1. Shulman ST, Phair JP, Sommers HM: Dasar Biologi dan Klinis Penyakit Infeksi. Edisi 4. Gajah Mada University Press. Yogyakarta. 1994.

2. Zurniati: Pengaruh pemberian ekstrak air daun kembang bulan (Tithonia diversifolia Hemsl.Gray) terhadap pertumbuhan Staphylococcus aureus dan Escherichia coli secara in vitro. Skripsi. Program Studi Pendidikan Dokter, Fakultas Kedokteran Universitas Syiah Kuala, Banda Aceh. 2011.

3. Kaur J, Kaur D, Singh H, et al. : Emblica officinalis: A meritocratic drug for treating various disorders. Indo American J. Pharm. Res.2013; 3(6): 4477-4496.

4. Sukanya MK, Suku S, Aruna: Phytochemical analysis, antimicrobial screening and antihelminthic properties of Phyllanthus emblica. Int. J. Pharm. Bio. Sci. 2013; 4(4): 55-64.

5. Raghu HS Ravindra: Antimicrobial activity and phytochemical study of Phyllanthus emblic. Int. J. Pharm. Stud. Res. 2010; 1: 30-33

6. Karsinah: Deteksi Salmonella. Universitas Airlangga. Surabaya. 2004.

7. Putri RWA: Identifikasi bakteri Escherichia coli dan Salmonella sp pada jajanan batagor di Sekolah Dasar Negeri di kelurahan Pisangan Cirendu, dan Cempaka Putih Kecamatan Cipitural Timur. Skripsi. Program Studi Kedokteran dan Profesi Dokter Fakultas Kedokteran dan Ilmu Kesehatan Islam Negeri Syarif Hidayatullah, Jakarta. 2016.

8. Suwito W: Distribusi serotipe salmonella dari rumah potong hewan (RPH) dan tempat pemotongan ayam (TPA) di Bogor. Widyariset. 2011; 14(2): 362.

9. Houghton PJ, Rahman A: Laboratory Handbook for The Fractionatiom of Natural Extract. Chapman dan Hall, London. 1998.

10. Ahmed B: 2007. Chemistry of Natural Products. Department of Pharmaceutical Chemistry Faculty of Science Jamia Hamdard, New Delhi. 2007.

11. Bombardelli E: Technologis for The Processing of Medicinal Plants. Di dalam R.O.B. Wijesekera. The Medicinal Plant Industry. CRC Press, Boca Raton. 1991

12. Madduluri $\mathrm{S}$, Rao KB, Sitaram B: In vitro evaluation of antibacterial activity of five indigenous plants extract against five bacterial pathogens of human. Int. J. Pharm. Pharm. Sci. 2013; 5(4): 679-84. 
13. Ahmed B: Chemistry of Natural Products. Department of Pharmaceutical Chemistry Faculty of Science Jamia Hamdard. New Delhi. 2007.

14. Cowan MM: Plant product as antimicrobial agents. Clin. Microbiol. Rev. 12: 564-582.

15. Bobbarala V Antimicrobial Agents. Intech, Croatia 21. Davis, W.W. and Stout, T.R. 1971. Disc plate method of microbiological antibiotic assay. J.Appl. Microbiol. 2012; 22(4): 659-665.

16. Ajizah A: Sensitivitas Salmonella typhimurium terhadap ekstrak daun Psidium guajava $L$. Bioscientiae. 2004; 1(1): 8-31.

17. Ganiswarna S: Farmakologi dan Terapi. Edisi 4. Universitas Indonesia, Jakarta. 1995.

18. Naim R: Senyawa Antimikroba dariTanaman. http://kompas.com/kompascetak/0409/15/sorotan/1265264.htm. 7 Januari 2019. 2004.

19. Dzulkarnain B: Tinjauan Hasil Penelitian Tanaman Obat di Berbagai Institusi. Edisi $2 . \quad$ Puslitbang Farmasi Badan Litbangkes Departemen Kesehatan RI, Jakarta. 1996.

20. Pelczar MJ, Chan ECS: Dasar-Dasar Mikrobiologi. UI Press, Jakarta. 2005
21. Pratama MR: Pengaruh ekstrak serbuk kayu siwak (Salvadora persica) terhadap pertumbuhan bakteri Streptococcus mutans dan Staphylococcus aureus dengan metode difusi agar. Laporan Hasil Penelitian. Program Studi Biologi. Fakultas MIPA Teknologi Sepuluh Nopember. 2005.

22. Davis WW, Stout TR: Disc plate method of microbiological antibiotic assay. J.Appl. Microbiol. 1971; 22(4): 659-665.

23. Kanazawa A, Ikeda $T$, Endo $T$ : A novel approach to mode of action of cationic biocides morfological effect bacterial activity. $J$. Appl. Bacteriol. 1995; 78: 55 60.

24. Nychas GJE: Natural antimicrobials from plants. Di dalam: Gould, G.W. (Ed). New Methods of Food Preservation. Blackie Academic and Profesional, London. 1995.

25. Zuhud EA, Rahayu WP, Wijaya $\mathrm{CH}$, et al. : Aktivitas antimikroba ekstrak kedawung (Parkia roxburghii $G$. Don) terhadap bakteri patogen. Jurnal Teknologi Industri Pangan. 2001 12: 6-12. 